\title{
The Trade in Medicinal Leeches in the Southern Indian Ocean in the Nineteenth Century
}

\author{
ROY T SAWYER*
}

The practice of bloodletting or phlebotomy was a predominant feature of western medicine in the eighteenth and nineteenth centuries, and the use of medicinal leeches as a mild form of letting blood achieved immense notoriety in the second quarter of the nineteenth century, especially in France. The almost insatiable demand for leeches drove a lucrative trade in these animals, the history of which has never been critically documented outside Europe.

By the end of the eighteenth century, France, England and other countries of western Europe had virtually depleted their indigenous stocks of the medicinal leech Hirudo medicinalis. To satisfy demand they were forced to import staggering numbers of this species from eastern Europe and the Levant, mainly by laborious overland transport. ${ }^{1}$ Throughout most of the nineteenth century the colonial powers had great difficulty in meeting their own medical needs, let alone in supplying their colonies.

Unfortunately, hardly anything is known about how colonial outposts satisfied their own demands for this much valued commodity. Of special interest in this context is Mauritius, an Anglo-French colony located in the southern Indian Ocean. This paper reveals that in the nineteenth century local pharmacists in Mauritius developed a longstanding alternative source of medicinal leeches by importing them directly from southern India by ship.

\section{The Importation of Leeches from India to Mauritius}

The National Archives, DBM Complex, Petite Rivière, Mauritius, proved to be a productive source of primary information on the trade in leeches in Mauritius in the nineteenth century. A search through selected issues of Le Cernéen, Journal de l'île Maurice, for the years 1833, 1848, 1864 and 1872, revealed advertisements for the sale of leeches placed by pharmacists in Port Louis. No issues were checked before 1833 or after 1872. The following is a sample of the advertisements that appeared during this forty year period:

*Roy T Sawyer, PhD, Medical Leech Museum, Bryngelen House, 2 Bryngwili Road, Hendy, Carms. SA4 1XB, UK. e-mail:

102364.1027@compuserve.com

I should like to thank the following for their invaluable assistance in Mauritius: Paul Sooprayen,
Chief Archivist, Petite Rivière; A Raheem Gopaul, Medical Entomology Division, Ministry of Health, Candos; Mahendra Koreeman; Claude Michel, Beau Bassin; and Yvan Martial, Vacoas.

I R T Sawyer, 'Why we need to save the medicinal leech', Oryx, 1981, 16: 165-8. 
[17 May 1833]

Belles sang-sues, à 8 p. le cent et 1 p. 50c. La douzaine, s'adresser à Mme. De Gaye, chez M. Lalouette, rue de l'Hôpital.

[31 May 1833]

Chez M. Grosjeau neveu, rue St. George: belles sangsues de l'Inde arrivées par l'Antoinette.

[Note: on 11 June 1833: "Arrivages ... La barque l'Antoinette, capit. Colin, partie de Madras, \& de Pondichéry le 15 Avril; cargaison riz et diverses marchandises. Passagers vingt Indiens.”]

[14 June 1833]

Belles sang-sues, de l'Inde, à une piastre la douzaine et cinq piastres le cent. S'adresser à Mme De Gaye, chez M. Lalouette.

[10 December 1833]

Sangsues à 1 piastre la douzaine et 6 piastres le cent, chez MM. Giquel \& Lequitte.

[2 March 1848]

Belles Sangsues de Pondichéry à $1 \mathrm{p}$. la douzaine.-S'adresser à M. Guiot ou à M. E. Fleurot.

[Note: previous recorded ships from Pondicherry reported on 22 February 1848: Brig. Mauritius Packet, 12 January, and bark East Anglian, 18 January, both "with sundries for this port".]

[4 March 1848]

Toujours de BELLES SANGSUES à 75 c. la douz. - Chez M.H.J. ANDERSON, à côté du Café des Marins, vis-à-vis le Bazar.

[24 June 1864]

Belles Sangsues. Par douzaine par cent, et par millier. - S'adresser à M. FLEUROT, Pharmacien. [Note: Monsieur Fleurot was selling leeches also in 1848.]

The most competitive year in this study was 1833 during which no fewer than five pharmacists were advertising these animals. Their rivalry is also reflected in the prices: on 17 May 1833 Mme de Gaye started advertising her leeches at 8 piastres per hundred and 1.5 piastres per dozen, but by 14 June she had dropped the price to 5 piastres per hundred and 1 piastre per dozen following an advertisement by a competitor on 31 May. Interestingly, the price remained generally constant for many years, and was still advertised as 1 piastre per dozen fifteen years later in 1848 .

One pharmacist, Monsieur Fleurot, was selling leeches in 1848, in competition with one other. Sixteen years later in 1864 he was still advertising, by which time there appeared to be no one else in the field. He must have been selling quite a number because he publicized them as available "by the dozen, by the hundred and by the thousand". By 1872 at least three pharmacists were advertising, but Fleurot was not amongst them. The three were: Mr B Perrot (67 rue Desforges, now Sir Seewoosagur Ramgoolan Street), Messrs A Minet \& Cie (24 rue de l'Eglise), and Mr Baissac (rue de la Corderie, and also at Chaussé).

The source of these leeches was clearly identified in the advertisements as being the French enclave of Pondicherry, in southern India. In several instances the specific ship which carried them was named. There is some evidence that the leeches were in transit for as long as four and even six weeks. For example, those advertised on 31 May 1833 had arrived on the Antoinette, which had left Pondicherry the previous 15 April (based on a notice of ship arrivals dated 11 June 1833). There was a distinct seasonality to the advertisements; most appeared between late February and June, and a very few between 
Chez M. Gronjeau neveu, rue St-George : belles sangsues de l'Inde arrivées par $r$ dnloincelte.

\section{A VENDRR.}

Bellcs sang-sues, 12 i la piastre et 5 piastres par cent, ruo de la Harpe, maison Ponibart père.

- En gros ou en délail, BELLES SANGSUES, rarizicics de Pondichéry par le navire l'Emmée.

S'adresser au magasin Heynemans.
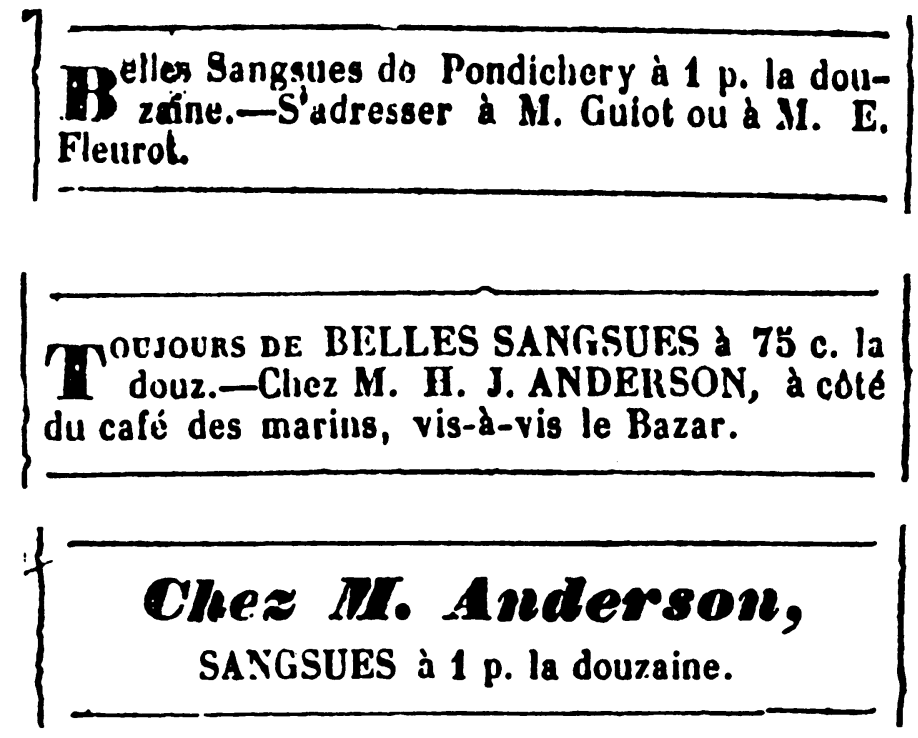

\section{Belles

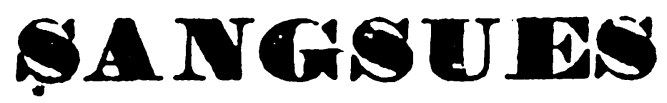

DE PONIDICHTEY.

S'adresser a la Pharmacio B. PERROT, rue Desforges, No. 67.

Figure 1: Representative advertisements by pharmacists in Port Louis, Mauritius, in the colonial newspaper Le Cernéen, Journal de l'île Maurice. From top: 31 May 1833, 18 June 1833, 6 December 1833, 2 March 1848, 4 March 1848, 1 April 1848, 25 April 1872. 
July and November. There is no evidence whatsoever that the imported leeches escaped and established themselves on the island of Mauritius. ${ }^{2}$

\section{Pondicherry, India: Centre for Exporting Leeches}

Clearly, Pondicherry was a major centre for the export of leeches for much of the nineteenth century. Unfortunately, as yet we know practically nothing about who the leech dealers were, how and where they procured their leeches, the identities of their other customers, and the purposes for which the leeches were purchased.

We know that in Mauritius leeches were imported for medical use by local pharmacists from as early as 1833 . Since they were advertised in the local newspaper, presumably they were also sold to the general public in some numbers and for a long time. One relevant factor may have been the increasing numbers of people of Indian descent on the island. With the abolition of slavery in 1835, many Indian labourers emigrated there. These people brought with them their ayurvedic medicine, a traditional medical practice which has continued to use leeches for over 2000 years. The use of leeches is described in considerable detail in Chapter XIII of the Sushruta Samhita, a collection of medical writings in the ayurvedic tradition dating back by some accounts to $200 \mathrm{BC}{ }^{3}$ The lowercaste labourers may have used leeches in their folk medicine and not necessarily as part of the more formalized ayurvedic practice.

One other instance of medicinal leeches being exported from India in the nineteenth century has been documented, but the context and time frame are different. ${ }^{4}$ With the abolition of slavery in the British West Indies in 1837 and in the French West Indies in 1848 , labourers were brought from India to work on the plantations. From the mid-1840s to the early 1870s each emigrant ship was required by the British government to have on board 100 leeches for each 100 passengers on the long journey to the West Indies. These leeches, which originated in northern India, primarily in the vicinity of Calcutta, the emigrants' main port of embarkation, have been identified as the Indian "cattle leech", Hirudinaria manillensis. Once in the West Indies they escaped and became established in Martinique, St Lucia and Puerto Rico.

The Mauritius study hints at the possibility that leeches could have been exported to the West Indies from southern India (Pondicherry), i.e. at least fifteen years before the British ships brought them with the emigrants. However, to date there is no evidence to support this.

We cannot yet determine from the evidence precisely which species of leech was imported from Pondicherry to Mauritius. It definitely would not have been the European Hirudo medicinalis, which is not native to the Indian subcontinent. ${ }^{5}$ Instead, it would have been one of the large, aggressive "cattle" leeches which are abundant in certain regions throughout India. The species used medically in India are usually either Hirudinaria

\footnotetext{
${ }^{2}$ Personal observation.

${ }^{3} \mathrm{~K}$ K Bhishagratna, An English translation of the sushruta samhita based on original Sanskrit text, Varanasi, India, Vidya Vidas Press, 1963, pp. 98-105.

${ }^{4}$ R T Sawyer, F O P Hechtel, J W Hagy, and E Scacheri, 'A study in medical history: introduction of
}

medicinal leeches into the West Indies in the nineteenth century', Zoosystema, 1998, 20 (3): 451-70.

${ }^{5}$ R T Sawyer, Leech biology and behaviour, 3 vols, Oxford University Press, 1986, vol. 2, p. 571. 
manillensis or Poecilobdella granulosa, which are indistinguishable externally and closely related. ${ }^{6}$ Moquin-Tandon did record that a medicinal leech, which he called "Hirudo granulosa", was "employed by the doctors of Pondicherry". Leuckart and Brandes observed, unfortunately without giving any further detail, that Hirudinaria at one time "was shipped out of India (Pondicherry) in large quantities to the islands of Bourbon and Mauritius". 8 In any case, we cannot assume that the species brought into Mauritius from southern India was the same as the Hirudinarina manillensis which originated in northern India and was successfully introduced to the West Indies.

${ }^{6} \mathrm{~W}$ A Harding, and J P Moore, 'Hirudinea', in The fauna of British India, including Ceylon and Burma, London, Taylor and Francis, 1927, pp. 226, 236-8.

${ }^{7}$ A Moquin-Tandon, Monographie de la famille des Hirudinées, Paris, Baillière, 1846, p. 341.
${ }^{8}$ R Leuckart, and G Brandes, 'Hirudineen', in Die Parasiten des Menschen und die von ihnen herrührenden Krankheiten. Ein Hand- und Lehrbuch für Naturforscher und Ärzte, Leipzig, C F Winter, 1901, pp. 535-897, on p. 879. 